\title{
VODOGRADBENI PROTIPOPLAVNI UKREPI ZA VARSTVO PRED ŠKODLJIVIM DELOVANJEM HUDOURNIŠKIH POPLAV KOT SESTAVNI DEL OBVLADOVANJA POPLAVNEGA TVEGANJA
}

Tajan Trobec, univ. dipl. geogr.

Oddelek za geografijo, Filozofska fakultete Univerze v Ljubljani

Aškerčeva 2, SI-I000 Ljubljana

e-mail: tajan.trobec@ff.uni-lj.si

Izvirni znanstveni članek

COBISS 1.01

Izvleček

Vodogradbeni protipoplavni ukrepi predstavljajo pomemben del varstva pred poplavami. Z njimi lahko obvladujemo določen del poplavnega tveganja. Njihov osnovni namen je zmanjševanje poplavne nevarnosti na poplavnih območjih, ki si jih je prisvojil človek s svojimi najrazličnejšimi dejavnostmi. Predstavljeni so nekateri najpogostejši vodogradbeni ukrepi za varstvo pred škodljivim delovanjem hudourniških poplav, njihov osnovni princip delovanja, glavne prednosti in slabosti ter vplivi na okolje.

Ključne besede: hidrogeografija, hidrologija, naravne nesreče, hudourniške poplave, hudourniki, erozija, vodogradbeni protipoplavni ukrepi

\section{STRUCTURAL MEASURES AS AN INTEGRAL PART OF FLASH FLOOD RISK MANAGEMENT}

\begin{abstract}
Structural measures play an important role in flood risk management. Their usage enables us to manage a certain part of flood risk. Their main purpose is to reduce flood hazard on flood-prone areas that have been inhabited or used for different human activities. The paper presents some of most common structural measures which serve for flash flood protection, the basic principle of operating, its advantages and disadvantages, as well as their environmental impact.
\end{abstract}

Key words: hydrogeography, hydrology, natural disasters, flash flood, torrent, erosion, structural measures 


\section{UVOD}

Slovenija je povirna dežela ter v strmem in vzpetem svetu, predvsem na območjih s slabo prepustno matično podlago, prepredena s številnimi hudourniškimi vodotoki (Hrvatin, 2002). Zanje je značilno zelo hitro odzivanje na padavinske dogodke, kar se kaže $\mathrm{v}$ nenadnem in znatnem povečanju pretokov. Izredni padavinski dogodki lahko na tovrstnih vodotokih privedejo do močne erozije, še zlasti v njihovih povirjih (Horvat, Jeršič, Papež, 2008), prenašanja in odlaganja velikih količin rečnega gradiva na hudourniške vršaje in v večje pritoke (lahko tudi v obliki drobirskih ter blatnih tokov) ter do pojava hudourniških poplav.

V zadnjem času je območje Slovenije prizadelo več hudourniških poplav, mdr. v letih 1990, 1998, 2007 in 2010, ki so terjale velik materialni davek, prizanesle pa niso niti človeškim življenjem. Zaradi visokih hitrosti vode in transporta velikih količin rečnega gradiva sodijo hudourniške poplave med najnevarnejše (FLOODsite, 2009). Sprožijo jih intenzivne padavine, ki jim sledi nenaden porast voda in povečanje pretokov, do česar pride praktično brez predhodnega opozorila. Pojavljajo se na obsežnem območju države, pretežno v ozkih dolinah gorovij, hribovij in gričevij (Komac, Natek, Zorn, 2008). Prihajajoče podnebne spremembe, ki naj bi botrovale vse bolj intenzivnemu vremenskemu dogajanju, se bodo zrcalile tudi v vse pogostejših hudourniških poplavah (Bates in sod., 2008). Glede na to lahko upravičeno sklepamo, da se bodo hudourniške poplave v prihodnje pojavljale tudi tam, kjer do sedaj niso bile tako značilne, zaradi česar bo varstvo pred njihovim škodljivim delovanjem še pomembnejše kot doslej.

V preteklosti je bila pogosta praksa, da smo posegali na poplavna območja hudourniških poplav, s čimer smo ogrozili sebe in svoje imetje, gospodarske dejavnosti, infrastrukturo, itd. Zaradi poplavne nevarnosti smo se bili primorani življenju na takih območjih na različne načine in v različni meri prilagoditi, in sicer predvsem z vodogradbenimi posegi v vodni in obvodni prostor (Brilly, Mikoš, Šraj, 1999). S spoznavanjem poplav ter $\mathrm{z}$ interdisciplinarnim pristopom $\mathrm{k}$ njihovemu preučevanju so se, še zlasti v razvitih družbah, postopno izoblikovale politike, ki se z namenom varstva pred škodljivim delovanjem voda vse bolj nagibajo h konceptu tako imenovanega obvladovanja poplavnega tveganja (FLOODsite, 2009; World Meteorological Organization, 2009). Slednji zajema paleto najrazličnejših ukrepov in dejavnosti za prilagajanje poplavam $\mathrm{V}$ najširšem smislu.

Eden izmed pomembnih elementov obvladovanja poplavnega tveganja so tudi vodogradbeni protipoplavni ukrepi, kot so zadrževalniki, nasipi, regulacije, pregrade, ipd., s katerimi preprečujemo škodljivo delovanje poplavnih voda na ogroženih območjih. Kljub temu da se jih je v zadnjem času pričel prijemati pridih preživetosti, ne smemo pozabiti, da so zaradi njihove intenzivne gradnje v preteklosti postali sestavni del kulturne pokrajine in jih je potrebno kot take tudi obravnavati, z vsemi prednostmi in slabostmi. 


\section{KONCEPT (SODOBNEGA) VARSTVA PRED POPLAVAMI, OZIROMA OBVLADOVANJE POPLAVNEGA TVEGANJA}

Ob poplavah vodotoki prestopijo bregove in voda preplavi obvodni prostor. Do poplav pride zaradi dolgotrajnih in/ali kratkotrajnih zelo intenzivnih padavin. Izključene niso niti antropogeno pogojene poplave, ki nastopijo zaradi neusklajenega delovanja ali porušitve vodogradbenih objektov, kot so vodne pregrade ali nasipi. Na pogostost in intenziteto poplav vpliva tudi spremenjena raba tal v porečju, na primer povečevanje deleža pozidanih površin ali krčenje gozda na račun pridobivanja kmetijskih površin, kar lahko privede do zmanjšane sposobnosti zadrževanja padavin in s tem do povečanega odtoka ob padavinskih dogodkih.

Da neko območje označimo za poplavno ogroženo, mora na njem obstajati objektivna nevarnost poplav kot tudi škodni potencial, ki ga predstavlja človek s svojimi najrazličnejšimi dejavnostmi v prostoru (poselitev, gospodarske dejavnosti, infrastruktura, itd.). Dejanska ogroženost nekega območja je zato odvisna tako od frekvence, intenzitete in narave poplavljanja, kot tudi od ranljivosti oziroma občutljivosti in vrednosti človekovih dejavnosti na tem območju. Ogroženost ob poplavah se nanaša na posameznika (izguba življenja, poslabšanje zdravstvenega stanja) in njegovo imetje, različne dejavnosti (kmetijske površine, trgovina, industrija), infrastrukturo (promet, infrastrukturna omrežja) ter na okolje (onesnaženje, kontaminacija, razlitja nevarnih snovi) (FLOODsite, 2009).

Poplave so na poplavnih območjih nekaj povsem običajnega, zaradi česar jih moramo obravnavati kot sestavni del pokrajine (Natek, 2007). S poseganjem na poplavna območja ogrožamo sebe in svoje imetje ter posledično nase prevzemamo določeno tveganje. Sodobni koncept varstva pred poplavami je v najširšem smislu zasnovan ravno na obvladovanju poplavnega tveganja. Pri tem obvladovanju se lahko osredotočimo bodisi na zmanjševanje poplavne nevarnosti, bodisi na zmanjševanje (obstoječe) ranljivosti, lahko pa tudi na samo preprečevanje vnosa škodnega potenciala na poplavna območja. Pri tem imamo na voljo vrsto preventivnih ali kurativnih, gradbenih, kot tudi negradbenih ukrepov in dejavnosti, ki se nanašajo na čas pred, ob in po nastopu poplave ter na čas med posameznima dogodkoma. Ukrepi in dejavnosti naj bi bili usklajeni na ravni celotnega porečja, pri soodločanju naj bi bili udeleženi vsi prizadeti.

Sodobni koncept varstva pred poplavami je izrazito večplasten in vključuje različne vzvode obvladovanja poplavnega tveganja, kot npr.:

- ustrezno in premišljeno prostorsko planiranje in rabo tal;

- pogozdovanje z namenom zmanjševanja odtočnega količnika in erozije;

- zadrževanje padavin na mestu nastanka;

- ohranjanje in obnavljanje površin za nadzorovano razlivanje presežkov vode;

- preprečevanje ali omejevanje razlivanja vode na pozidanih poplavnih območjih;

- napovedovanje poplav;

- pravočasno opozarjanje na bližajočo nevarnost s pomočjo medijev in alarmiranja;

- pripravljenost in ustrezen odziv v sili;

- ozaveščanje prebivalcev o poplavni nevarnosti;

- informiranje o možnostih samozaščite in samopomoči ob nastopu poplave; 
- protipoplavna gradnja;

- prepoved gradnje na poplavnih območjih ali preselitev določenih dejavnosti s poplavnih območij;

- razprševanje tveganja v obliki zavarovalništva;

- hitra in učinkovita popoplavna obnova, itd. (Guidance ..., 2007; Brilly, 2001; FLOODsite, 2009; Mikoš, 2010; World Meteorological Organization, 2009).

Krovni dokument, ki ureja področje varstva pred poplavami na ravni Evropske unije, je Direktiva 2007/60/ES Evropskega parlamenta in Sveta z dne 23. oktobra 2007 o oceni in obvladovanju poplavne ogroženosti (Direktiva, 2007), oziroma krajše poplavna direktiva. Slednja je bila prenesena tudi v slovensko zakonodajo, in sicer:

- z razglasitvijo Zakona o spremembah in dopolnitvah Zakona o vodah (Zakon ..., 2008);

- s sprejetjem Pravilnika o metodologiji za določanje območij, ogroženih zaradi poplav in z njimi povezane erozije celinskih voda in morja, ter o načinu razvrščanja zemljišč v razrede ogroženosti (Pravilnik ..., 2007);

- z izdajo Uredbe o pogojih in omejitvah za izvajanje dejavnosti in posegov v prostor na območjih, ogroženih zaradi poplav in z njimi povezane erozije celinskih voda in morja (Uredba ..., 2008);

- Uredbe o vsebini in načinu priprave podrobnejšega načrta zmanjševanja ogroženosti pred poplavami (Uredba ..., 2010).

Poplavna direktiva nalaga državam članicam pripravo kart poplavne nevarnosti (do konca leta 2011) in poplavne ogroženosti (do konca leta 2013), za ogrožena območja pa tudi izdelavo načrtov za obvladovanje poplavne ogroženosti (do konca leta 2015). Slednji naj bi obravnavali vse vidike obvladovanja poplavne ogroženosti s poudarkom na preprečevanju, varstvu, pripravljenosti, napovedovanju in opozarjanju (Direktiva, 2007).

V nadaljevanju se bomo omejili na obravnavo vodogradbenih oziroma gradbeno-tehničnih protipoplavnih ukrepov.

\section{VODOGRADBENI PROTIPOPLAVNI UKREPI}

Vodogradbeni protipoplavni ukrepi predstavljajo pomemben del obvladovanja poplavnega tveganja. Njihov osnovni namen je zmanjševanje poplavne nevarnosti na poplavnih območjih. $Z$ njimi lahko vplivamo na nastanek ali vir nevarnosti (na primer z zadrževalniki, ki zmanjšujejo konico poplavnega vala) ali pa branimo določeno območje pred škodljivim delovanjem voda (na primer $\mathrm{z}$ nasipi ali regulacijami vodotoka skozi naselje) (Kozelj in sod., 2008). Na manjših hudourniških vodotokih z njimi na različne načine vplivamo predvsem na zmanjševanje strmca in transporta rečnega gradiva (na primer z zaplavnimi pregradami).

V preteklosti je veljalo zmotno mnenje, da ni tako velikih poplav, ki jih z vodogradbenimi protipoplavnimi ukrepi ne bi mogli preprečiti (Anzeljc in sod., 1995; Brilly, Mikoš, Šraj, 1999; World Meteorological Organization, 2009). Zavedati se moramo, da na poplavnih območjih absolutne varnosti zgolj z gradbeno-tehničnimi protipoplavnimi ukrepi ni možno doseči. Raven varovanja je v določeni družbi, glede na potrebe 
ter glede na obstoječi pravni, ekonomski in okoljski vidik, vedno določena z izbranim projektnim pretokom, ki je podlaga za načrtovanje protipoplavnih ukrepov (Kozelj in sod., 2008).

Projektni pretok je pri nas na urbanih površinah navadno vezan na t.i. stoletne vode $\left(\mathrm{Q}_{100}\right)$ (Brilly, Mikoš, Šraj, 1999). Slednje v praksi pomeni, da naj bi se naselja varovala pred poplavami, ki se v povprečju pojavljajo enkrat na sto let. Projektni pretok predstavlja tudi zgornjo mejo tako imenovanega prevzetega tveganja za prebivalce in dejavnosti na varovanem poplavnem območju. Večji poplavni dogodki se namreč štejejo za višjo silo in predstavljajo tako imenovano preostalo tveganje (Kozelj in sod., 2008), ki pa ga zaradi preseženega projektnega pretoka s klasičnimi vodogradbeni protipoplavni ukrepi ne moremo obvladovati. Preostalo tveganje je možno do določene mere zmanjšati z dopolnilnimi protipoplavnimi ukrepi, kot so protipoplavna gradnja, sekundarna obrambna linija, pravočasna evakuacija in podobno.

Zavedati se moramo, da se objekti za varstvo pred poplavami, v primeru dotrajanja, neprimernega vzdrževanja ali nastopa izredno visokih voda, lahko poškodujejo ali porušijo. Tedaj so posledice še veliko bolj katastrofalne, kot bi bile, če teh objektov ne bi bilo. Izvedeni vodogradbeni ukrepi namreč ugodno vplivajo na razvoj različnih dejavnosti na območjih, ki smo jih iztrgali reki, kar vpliva na povečevanje ranljivosti in posledično na še večjo škodo v primeru poplave (Brilly, Mikoš, Šraj, 1999; Černe, 2005; Plut, 2005; Natek, 2007). Izvedeni protipoplavni ukrepi vplivajo tudi na popolno odsotnost poplavljanja ob običajnih visokih vodah, kar vzbuja občutek lažne varnosti in nas odvrača od misli, da smo prisotni na poplavnem območju. Zagotovljena varnost pred običajnimi visokimi vodami nas zlahka zavede, da povsem odmislimo morebitne posledice v primeru preseženega projektnega pretoka, zaradi česar se ranljivost na varovanem območju navadno le še povečuje.

Vodogradbeni protipoplavni ukrepi predstavljajo eno prvih oblik 'boja' proti škodljivemu delovanju voda. Zgodnji ukrepi so se v glavnem omejevali na lokalne posege, pogosto na škodo neposrednih sosedov na sosednjem bregu ali dolvodno (Mikoš, 2000). V preteklosti so bili ti ukrepi izrazito enostranski in niso upoštevali gorvodnih in dolvodnih ureditev na vodotoku. Po svoji naravi so bili pogosto precej togi in v neskladju z načeli varstva okolja. Mnogokrat so se za zagotavljanje poplavne varnosti izbirale najenostavnejše hidravlične rešitve (Vignozzi in sod., 1999), ki so pogosto imele za posledico geomorfološko in ekološko razvrednotenje posameznih odsekov vodotokov (Marušič, Penko Seidl, Drašler, 2005). Danes vse bolj stopajo v ospredje zahteve po okolju prijaznejših rešitvah. Novodobni gradbeno-tehnični posegi na vodotokih naj bi bili bolj premišljeni, čim bolje vpeti v naravno okolje in usklajeni na ravni celotnega porečja. Vzpodbuja se tudi uporaba naravnih materialov. Ureditvam, ki niso neizbežno potrebne, se raje poskušamo izogniti in jih nadomestiti z alternativnimi protipoplavnimi ukrepi (Direktiva, 2007). V zadnjem času se deloma uveljavlja renaturacija vodotokov, ki so jih prizadele nekdanje toge ureditve, pri čemer se z različnimi posegi na vodotokih poskuša ponovno vzpostaviti čim bolj naravnemu podobno stanje (Vrhovšek, Vovk Korže, 2008; World Meteorological Organization, 2006). 
Pri načrtovanju vodogradbenih protipoplavnih ukrepov je potrebno upoštevati različne vidike nevarnosti ob hudourniških poplavah, kot so nenadno zvišanje vodne gladine, velika hitrost vodnega toka, velika udarna sila vode ter izrazita erozijska in transportna sposobnost, ki se kažeta $\mathrm{v}$ prenašanju velikih količin najrazličnejšega gradiva. Razdiralna moč vode je pri hudourniških poplavah veliko večja kot pri nižinskem in kraškem tipu poplav (Natek, 2005). Zaradi tega se je pred njimi težko obvarovati, gradbeno-tehnični ukrepi pa morajo biti premišljeno izbrani in ustrezno prilagojeni, da prenesejo izredne obremenitve. Pomembno je, da so rečna korita normalno pretočna in brez večjih ovir, ki bi lahko preprečevale odtok (na primer preozki prepusti, prenizki mostovi in podobno). Za hudourniške poplave v splošnem velja, da je zmanjševanje nevarnosti manj učinkovito od zmanjševanja ranljivosti. $Z$ drugimi besedami - pred njimi se je veliko bolje umakniti na varno območje, kot pa računati na protipoplavno zaščito (FLOODsite, 2009).

Hudourniške poplave pogosto nastanejo $\mathrm{v}$ manjših porečjih, ki navadno niso opremljena $\mathrm{z}$ vodomernimi postajami, zaradi česar ne razpolagamo s podatki o vodostajih/pretokih. Tudi v primeru, ko je nek hudourniški vodotok opremljen z vodomerno postajo, ta nemalokrat ne zabeleži maksimalnih pretokov, ki so potrebni za izračunavanje povratne dobe, saj jo voda ob nastopu poplave hitro poškoduje. Na hudourniških vodotokih je zato težko izračunati hipotetični pretok za določeno povratno dobo, zaradi česar ga lahko pri načrtovanju vodogradbenih protipoplavnih ukrepov le ocenimo. Pri tem si lahko pomagamo s prenosom podatkov o pretokih z vodomernih postaj iz bližnjih in geografsko podobnih porečij (Trobec, 2008). Pomagamo si lahko tudi z različnimi modeli odtoka padavinskih voda ali z enačbami visokih voda, ki upoštevajo specifične odtoke in velikost porečja (Mikoš, 2000). Višino ekstremnih poplav lahko ponekod rekonstruiramo iz različnih sledi visokih voda $\mathrm{v}$ pokrajini (Natek, 2002; Papež, 2011), fotografij, pričevanja lokalnega prebivalstva, itd. Pri tovrstnem računanju oziroma ocenjevanju vedno obstaja možnost, da smo pretok podcenili. Če je projektni pretok podcenjen, se posledično poveča tudi poplavna ogroženost na varovanem območju.

V nadaljevanju predstavljamo nekatere najznačilnejše vodogradbene ukrepe, ki se uporabljajo za varstvo pred hudourniškimi poplavami.

\section{I. Protipoplavni nasipi}

Protipoplavni nasipi predstavljajo najstarejšo zgradbo za varstvo pred poplavami (Vignozzi in sod., 1999; Ward, 1978). Potekajo vzdolž rečnega toka, njihov osnovni namen pa je, da onemogočajo prosto razlivanje visokih voda po poplavnem območju. Lahko so zgrajeni na obeh ali pa le na eni strani vodotoka, lahko gre za neprekinjene ali za izmenične zgradbe na zunanjih straneh zavojev (Mikoš, 2000). Zgrajeni so lahko neposredno ob brežini, ali pa so od osnovne struge znatno oddaljeni, kar je odvisno predvsem od vrednosti obvodnega zemljišča, izoblikovanosti površja, pretočnih količin, ipd. (Kuzmič, Suhadolnik, 2005). Obsežnejši nasipi so navadno zgrajeni v srednjem in spodnjem toku reke, v zgornjem toku so praviloma manjši in lokalno omejeni. 
Že iz imena je razvidno, da gre pri nasipih za objekte zgrajene iz nasutega materiala (zemlja, pesek). Slednje sicer ni pravilo, saj so na območju urbanih površin, kjer je manj prostora, lahko zgrajeni tudi kot betonske stene. Takšni nasipi so neprimerno dražji in tudi z okoljevarstvenega vidika bolj obremenjujoči za okolje, še zlasti izven naselij (Vignozzi in sod., 1999). Nasipi morajo biti neprestano pod nadzorom in primerno vzdrževani, sicer lahko za območja, ki jih varujejo, predstavljajo resno grožnjo. Večje poplave lahko zaradi velike moči vode, mehanskih poškodb ob udarcih večjih prodnikov ter erozijskega delovanja vode nasipe poškodujejo. Material v nasipih se lahko sčasoma tudi posede. Večja drevesa, ki zrastejo na nasipih, izoblikujejo s koreninami sistem kanalov, ki oslabijo konstrukcijo nasipa. Pri odmrlih drevesih ostanejo za strohnelimi koreninami rovi, ki jih ob visokem vodostaju zalije voda. Ta v nasipu povzroči notranjo erozijo, ki izpira material in spodbudi dodatno posedanje nasipa ali zdrs brežine, zaradi česar lahko visoka voda nasip prelije in ga popolnoma uniči (Brilly, Mikoš, Šraj, 1999). Podobne posledice lahko povzročijo tudi brlogi, ki si jih v nasipih gradijo nekatere obrečne živali (Mikoš, 2000).

Nasipi ponavadi varujejo daljše rečne odseke. Učinkovitost tovrstne ureditve je odvisna od najšibkejšega dela nasipa. Dovolj je namreč, da nasip ob poplavi popusti le na enem mestu in voda se prosto razlije po poplavnem območju. Nevarnost predstavljajo še zlasti starejši nasipi, ki so bili zgrajeni iz bližnjih, razpoložljivih in pogosto manj kakovostnih materialov (Mikoš, 2000). Grožnjo za poškodovanje in porušitev nasipov pomenijo zlasti hudourniške poplave, tako zaradi velike hitrosti vode kot izrazite erozijske sposobnosti in transporta različnega rečnega gradiva.

Območja, ki jih nasipi varujejo, se v gospodarskem in poselitvenem smislu še naprej bolj ali manj nemoteno razvijajo, s čimer se njihova ranljivost neprestano povečuje. V praksi je za zagotavljanje enake ravni varnosti nasipe sčasoma potrebno povišati (Brilly, Mikoš, Šraj, 1999).

Okoljski učinki nasipov so večplastni. V prvi vrsti so nasipi fizična ovira za živali, ki so nerazdružljivo povezane z reko. Ker preprečujejo prelivanje vode po naplavni ravnici, s tem siromašijo obvodne ekosisteme. Z okoljevarstvenega vidika so bistveno bolj sprejemljivi geometrijsko nepravilno oblikovani kot pa premočrtno potekajoči nasipi. Za razvoj rečnih in obrežnih habitatov je pomembno, da so nasipi odmaknjeni od rečnega brega, s čimer se omogoči nemoten morfološki razvoj struge (Vignozzi in sod., 1999). Nasipi, ki so blizu rečnega brega, so zaradi rečne erozije bolj ogroženi. Ob visokih vodostajih vplivajo nasipi na hitrejše odtekanje voda $v$ spodnje dele porečja, kar povečuje poplavno nevarnost dolvodno od mesta izgradnje nasipov.

Večji in sklenjeni nasipi tudi pri nas varujejo poplavne ravnice pred razlivanjem visokih voda na številnih rečnih odsekih. Navadno so zgrajeni v srednjem in spodnjem, ravninskem delu vodotokov ter v vmesnih razširjenih dolinah in kotlinah (na primer ob Muri, Savinji, Kamniški Bistrici, Dragonji, itd.). Ob manjših vodotokih so ponekod nasuti nižji in nesklenjeni nasipi za lokalno zaščito posameznih objektov ali kmetijskih površin pred vsakoletnimi visokimi vodami. Leta 1998 smo imeli v Sloveniji zgrajenih $872 \mathrm{~km}$ nasipov, od tega dobrih 83 \% v porečjih Mure in Drave (Statistični letopis, 1999), številka se do danes ni bistveno spremenila. 
Slika 1: Protipoplavni nasipi ob spodnjem toku Dragonje

Figure 1: Embankments along the lower section of the Dragonja River

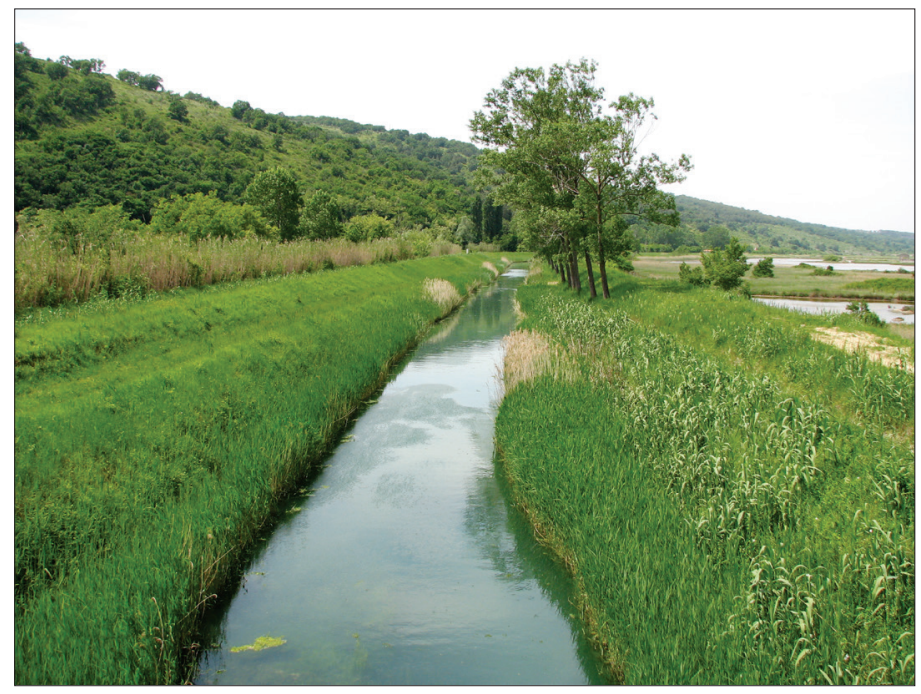

\subsection{Zadrževalniki}

Zadrževanje vode je eden osnovnih načinov t.i. aktivnega varstva pred visokimi vodami. Zasnovano je tako, da se v času visokih voda del poplavne vode zadrži na za to predvidenih površinah, kar vpliva na dolvodno zmanjšanje pretoka. Zadržano vodo se ob upadanju pretoka kontrolirano vrača nazaj v vodotok. Z zadrževanjem vode navadno ne vplivamo na samo prostornino poplavnega vala, temveč zgolj na njegovo višino in časovni potek (Vignozzi in sod., 1999). Na račun podaljšanega trajanja poplavnega vala se omili njegova konica. Zadrževanje vode se navadno začne šele, ko je presežen določen kritični pretok, zaradi česar manj izrazitih visokovodnih valov niti ne zadržujemo. Kot pri ostalih protipoplavnih ukrepih, tudi pri zadrževanju ne gre računati na absolutno varnost, saj je njegov vpliv pri ekstremno velikih poplavah praktično izničen (Brilly, Mikoš, Šraj, 1999).

Možnih načinov zadrževanja vode je veliko, najbolj značilne namenske zgradbe so zadrževalniki, ki so lahko mokri ali suhi. V mokrih zadrževalnikih je voda prisotna ves čas in so pravzaprav nekakšna umetna jezera, ki so nastala za pregrado. Navadno so večnamenski, saj so poleg zadrževanju poplavne vode namenjeni tudi ostalim dejavnostim (oskrba z vodo, namakanje, bogatenje nizkih pretokov, ribolov, turizem, rekreacija, krajinska podoba stoječe vode, ipd.).

Za razliko od mokrih so suhi zadrževalniki večino časa brez vode. Namenjeni so izključno zadrževanju visokih voda, njihova efektivna zmogljivost zadrževanja pa je posledično večja kot pri mokrih zadrževalnikih. Postavljeni so lahko na samem vodotoku ali v njegovi bližini. Med suhe zadrževalnike lahko uvrstimo tudi t.i. retenzije. 
To so z nasipi obdane, večinoma travnate površine neposredno ob vodotoku. Podobno kot zadrževalniki so tudi retenzije namenjene zadrževanju visokih voda, le da voda iz reke vanje doteka bočno prek sistema zapornic in prelivov (Brilly, Mikoš, Šraj, 1999).

V zadrževalnikih se zaradi stoječe vode kopičijo naplavine, ki jih je treba občasno odstraniti, da se zagotavlja zadostna prostornina za zadrževanje vode. Mokri zadrževalniki povsem zajezijo vodotok in ga na določenem odseku spremenijo v stoječo vodo, kar vpliva na drugačne življenjske pogoje ter na spremenjeno sestavo živalskih in rastlinskih vrst. Neustrezno zasnovani prepusti zadrževalnikov ter odsotnost ribjih stez onemogočajo nemoteno prehajanje vodne favne, s čimer je v vodotoku prekinjen rečni kontinuum (Vannote in sod., 1980), kar negativno vpliva na razmnoževanje, rast in razvoj vodnih organizmov (Kolman, Mikoš, Povž, 2010). Spremenjeni pogoji lahko negativno vplivajo na kvaliteto vode, večji zadrževalniki lahko vplivajo na spremenjeno višino podtalnice, itd. (Steinman, Banovec, 2008; World Meteorological Organization, 2006). Suhi zadrževalniki in retenzije imajo na drugi strani manjši vpliv na vodotok in obvodni prostor, ker je voda v njih prisotna samo občasno, je pa zanje potrebno zelo veliko dragocenega prostora in predstavljajo zelo velik poseg v sicer dobro ohranjeno kmetijsko ali celo naravno okolje.

V Sloveniji je bilo doslej za varovanje urbanih območij pred poplavami zgrajenih več kot 30 visokovodnih zadrževalnikov (Starec, 2002). Prav veliko prostora za večje nove zadrževalnike ni, saj jih je na ravnini težje izvesti, v vzpetem svetu pa prevladujejo ozke doline in grape, kjer je težko s še sprejemljivo pregradno višino doseči večje zadrževalne prostornine (Mikoš, 2000). Kljub temu je bilo evidentiranih več kot 750 potencialnih lokacij za gradnjo novih zadrževalnikov, pri čemer je potrebno poudariti, da se posamezne izmed njih medsebojno izključujejo (Starec, 2002). Nekateri visokovodni zadrževalniki pri nas že sedaj vsaj deloma služijo obrambi pred hudourniškimi poplavami (na primer Šmartinsko in Slivniško jezero ter zadrževalnika Vanganel in Drtijščica). V načrtu je izgradnja še nekaterih suhih zadrževalnikov za zaščito pred hudourniškimi poplavami; na primer zadrževalnik Razori v porečju Gradaščice (Fazarinc, 2010), ter sistem več suhih zadrževalnikov v Spodnji Savinjski dolini za zaščito pred poplavami Savinje in nekaterih pritokov (Skutnik, 2005). Po uničujoči hudourniški poplavi v Železnikih leta 2007 so za zaščito naselja med drugim predvideli tudi izgradnjo 21-metrske dolinske pregrade, za katero bi nastal suhi zadrževalnik Jesenovec. Pregrado naj bi postavili približno 1,5 km gorvodno od Železnikov (Černe, Ilc, 2007). 
Slika 2: Zadrževalnik Vanganel na Bavškem potoku v porečju Badaševice

Figure 2: Vanganel detention reservoir on the Bavški potok torrent in the drainage basin of Badaševica

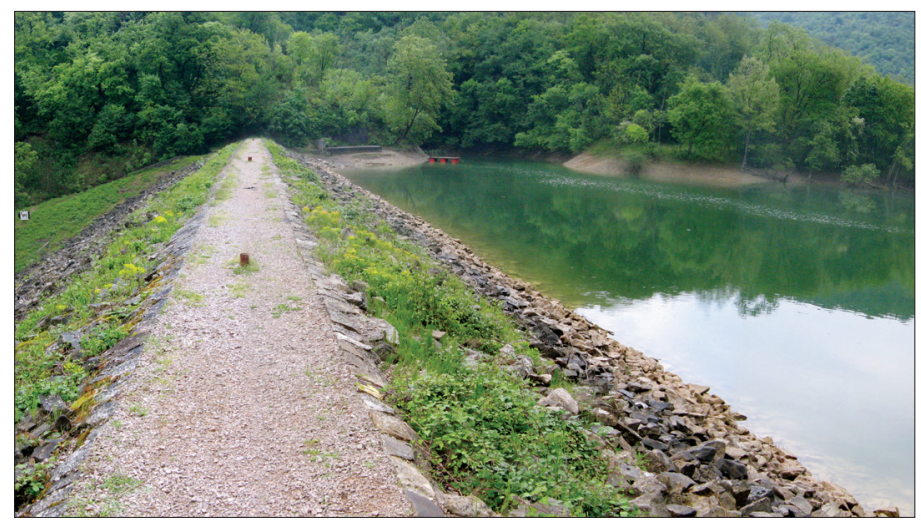

\subsection{Regulacije}

Struge naravnih vodotokov lahko prevajajo le omejene količine vode. Ob poplavah voda prestopi bregove in se prične razlivati po poplavni ravnici. Vodotok tedaj pospešeno erodira ali odlaga material, ki ga prinaša s seboj, med poplavo pa si lahko vreže tudi povsem novo strugo. Tovrstne, z vidika rabe obvodnega prostora nezaželene pojave lahko s pomočjo reguliranja in kanaliziranja vodotokov do določene mere omejimo. Včasih pomaga že sprotno čiščenje in redno vzdrževanje struge.

$\mathrm{Z}$ regulacijo vodotokov poskušamo doseči večjo pretočno sposobnost struge za vodo ter za transport plavin, s čimer omejimo poplavljanje in nasipavanje rečnega gradiva ter posledično dvigovanje rečnega dna. Na reguliranem odseku lahko vplivamo tudi na stabilizacijo struge ter na preprečevanje erozije (še zlasti bočne). Najbolj običajni ukrepi, ki se jih ob regulacijah poslužujemo so: razširitev oziroma poglobitev struge, sprememba tlorisnega poteka struge (izravnava ter skrajšanje vodotoka), ki ima za posledico povečanje strmca, sprememba hidravličnega radija ter oblaganje bregov (v ekstremnih primerih lahko tudi dna) struge z gladkimi materiali, kar povzroča manjše trenje in zato večje hitrosti vode (Mikoš, 2000; Ward, 1978). Z navedenimi ureditvami poskušamo strugo prilagoditi za odvajanje pretočnih viškov brez škode za okoliška zemljišča vse do višine projektnega pretoka. Zaradi skrajšanja vodotoka, odsotnosti razlivanja poplavne vode ter povečane hitrosti vodnega toka na reguliranih odsekih lahko regulacije še stopnjujejo hudourniški značaj vodotoka in povzročijo poplavljanje dolvodno od izvedenih ureditev. Kanalizirani odseki so zaradi povečanega strmca in hitrejšega vodnega toka nagnjeni k eroziji in posledičnemu poglabljanju struge, dolvodni odseki pa k povečanemu naplavljanju rečnega gradiva. Regulacije struge zato pogosto spremljajo različni dopolnilni ureditveni ukrepi, kot na primer postavitev pragov, drč, ipd. 
Regulacije lahko vodijo v krajinsko in estetsko težko sprejemljive rešitve (Mikoš, 2000). Poleg tega predstavljajo grob poseg v naravno okolje, saj lahko popolnoma prekinejo stik med vodotokom in obvodnim prostorom (Wohl, 2004). Hitrejše odtekanje vode je še zlasti problematično v času nizkih vodostajev, ko se voda v predimenzioniranih strugah še bolj porazgubi. Večje regulacije lahko med drugim vplivajo na spreminjanje gladine podtalnice, $\mathrm{v}$ ekstremnih primerih je stik med podtalno in površinsko vodo celo povsem prekinjen. Z regulacijami so izničeni mehanizmi naravnega morfološkega oblikovanja struge. Regulirani vodotoki le malo vijugajo, ni več menjavanja odsekov hitreje in počasneje tekoče vode, ne nastajajo brzice in vmesni tolmuni, s čimer je osiromašena pestrost vodnih in obvodnih habitatov, kar vpliva na zmanjšano biodiverziteto. Kanalizirani vodotoki imajo tudi omejene samočistilne sposobnosti. Šele v zadnjem času se tako v tujini kot pri nas uveljavljajo zahteve po renaturaciji kanaliziranih vodotokov (Vrhovšek, Vovk Korže, 2008; World Meteorological Organization, 2006).

Regulacije vodotokov so bile v preteklosti najbolj pogosto uporabljen protipoplavni ukrep pri nas (Kuzmič, Suhadolnik, 2005), tako da je reguliranih skoraj $1650 \mathrm{~km}$ vodotokov, obrežnih ureditev pa je še za 948 km (Statistični letopis, 2004). Njihov cilj je bil utesniti delovanje vode na čim manjši prostor, površine ob vodotokih, ki so bile pred tem občasno izpostavljene poplavljanju, naplavljanju ali eroziji, pa so namenili drugim dejavnostim (Brilly, Mikoš, Šraj, 1999). Regulacije so se pogosto izvajale tudi na hudourniških vodotokih, ki prenašajo velike količine plavin in za katere so značilne hudourniške poplave. Tovrstni ukrepi se v zadnjem času zaradi negativnih stranskih učinkov (povečan hudourniški značaj vodotokov, okoljski vidik) vse bolj opuščajo. Dovoljujejo se le še krajše ureditve za zaščito preostalih kritičnih poseljenih območij ter infrastrukture. Ureditve morajo biti izvedene čim bolj sonaravno, z naravnimi materiali, obenem pa ne smejo bistveno vplivati na dolvodni pretočni režim (Kuzmič, Suhadolnik, 2005). Regulacije so pri nas pogoste še na hudourniških vršajih, kjer so vodotoki speljani v razširjena, poglobljena ter obzidana korita, t.i. kinete. Slednje morajo biti redno vzdrževane, sicer lahko hudourniki ob izdatnem deževju na vršaju zlahka prestopijo bregove, preplavijo in zasujejo obsežne površine ter si zarežejo novo strugo v povsem drugem delu vršaja.

\subsection{Prečni vodogradbeni objekti}

Hudourniške poplave se pogosto pojavljajo v povirjih, kjer zaradi velikih strmcev in malo razpoložljivega prostora gradnja klasičnih gradbeno-tehničnih protipoplavnih objektov, kot so zadrževalniki ali nasipi, ne pride v poštev (Guidance ..., 2007). Slednje lahko dokaj uspešno nadomestimo s prečnimi vodogradbenimi objekti, kot so pragovi, drče, jezovi, zaplavne pregrade, ipd. S prečnimi vodogradbenimi objekti vplivamo na izoblikovanje in potek podolžnega profila vodotoka, s čemer blažimo negativne učinke erozije in poplavljanja. V nadaljevanju je podan zgoščen opis nekaterih hidroloških in geomorfnih procesov na območjih hudourniških vodotokov, ki jih lahko do določene mere blažimo z gradnjo prečnih gradbeno-tehničnih objektov. 
Ko se po hudourniških vodotokih pomikamo gorvodno proti povirjem, postopno prehajamo v vse višja in strmejša območja. Količina vode v vodotokih je sicer vse manjša (večji del leta je lahko struga suha), strmci pa se povečujejo. Ob obilnih in intenzivnih padavinah se v povirjih zaradi nenadnega, tudi večstokratnega povečanja pretokov znatno poveča transportna moč vodotokov. Poveča se tudi erozijska sposobnost, zaradi česar se vodotoki globinsko in bočno vrezujejo v pobočja in jih pri tem spodkopavajo. S tem se povečuje nevarnost za postopno ali nenadno plazenje velikih količin pobočnega materiala v struge hudournikov. Nestabilna matična podlaga lahko v povezavi z neustrezno rabo tal na takih območjih privede do nastanka erozijskih žarišč. Ob ekstremnih pretokih prinašajo hudourniški vodotoki v doline poleg vode tudi obilico najrazličnejšega rečnega gradiva (pesek, prod, grušč, skale, vejevje, drevesna debla, ipd.), zaradi česar je njihov učinek še toliko bolj razdiralen. Vodotoki se tedaj prelijejo prek brežin in poplavljajo vse, kar jim stoji na poti, obenem spodkopavajo in odnašajo bregove ter prestavljajo struge. Opisane učinke lahko do določene mere omilimo z izgradnjo prečnih vodogradbenih objektov. V ta namen lahko uporabimo še različna obrežna zavarovanja in regulacije, pa tudi različne biotehnične ukrepe (Florineth, 2004), ki niso več predmet tega prispevka.

Ob spletu neugodnih dejavnikov (ekstremni nalivi, veliki nakloni pobočij, velike količine labilnega gradiva, porušenje lokalne zajezitve, pomanjkanje rastlinskega pokrova, itd.) se v strugah lahko pojavijo drobirski ali blatni tokovi, ki so zaradi velike hitrosti in mase še posebej nevarni (Komac, Zorn, 2007; Mikoš, 2009).

Zaradi zmanjšanega strmca vodotoki na vršajih in v dolinah odlagajo material ter zasipavajo strugo in poplavno ravnico. Krčenje gozdov, obdelovanje tal, poselitev višjih predelov, izgradnja infrastrukture, idr. so ponekod privedli do dviga poplavne ravnice in razširitve poplavnega sveta $\mathrm{v}$ dnu dolin ter posledično do povečane ogroženosti naselij, ki ob svojem nastanku poplav verjetno niso niti poznala (Šifrer, 1983).

Zelo razširjeni in tudi $v$ naravi najbolj razpoznavni prečni objekti so t.i. zaplavne hudourniške pregrade. Gre za manjše, a lahko tudi več metrov visoke objekte, zgrajene iz betona, kamna, kamna v betonu, žičnih košar ali lesa, s katerimi pregradimo hudourniško strugo (Vignozzi in sod., 1999). Za njimi se zaradi dotoka rečnega gradiva sčasoma nabere zaplavek iz proda, peska in grušča. Na mestu, kjer je postavljena pregrada, se struga umetno zviša in utrdi, zato pregrade predstavljajo fiksne točke v podolžnem rečnem profilu.

Zaplavne hudourniške pregrade se gradijo predvsem v zgornjih delih hudournikov, kjer so strmci še vedno veliki in kjer je prisoten transport večjih količin rečnega gradiva. Služijo predvsem zmanjševanju strmca gorvodno od pregrade, kar vpliva na počasnejši tok vode ter na zmanjšano transportno moč. Prek pregrade voda prosto pada, pod njo pa zadene ob podslapje ali erozijski tolmun, pri čemer se del njene energije porabi. Pregrade, za katerimi se je nabral zaplavek, tudi zavirajo globinsko in bočno erozijo vodotokov gorvodno od njih, zato voda pobočij ne spodkopava več tako intenzivno. V vodotoke se posledično prožijo manjše količine pobočnega materiala, s čimer se dodatno umirjata dotok in transport plavin. Stabilizacija hudournikov s pomočjo zaplavnih pregrad je zato pogost spremljevalec pri pogozdovanju in sanaciji erozijskih žarišč (Mikoš, 2009). 
Pregrade vplivajo tudi na pretočni maksimum ob ekstremnih pretokih, saj ga zaradi zmanjšanega strmca do določene mere ublažijo. Slaba stran pregrad je v tem, da pogosto predstavljajo nepremostljivo oviro za ribje migracije. Večina pregrad pa je $\mathrm{v}$ zgornjih delih hudourniških vodotokov (Vignozzi in sod., 1999), kjer so pogoji za življenje rib manj ugodni in bi bile ribje poti tudi po naravni poti pogosto prekinjene, deloma zaradi majhnih pretokov in občasnega presihanja vode, deloma zaradi obstoječih naravnih stopenj v strugi. Pri izgradnji zaplavnih pregrad v nižjih delih hudournikov, kar sicer ni pogost pojav, lahko nemoteno prehajanje rib zagotovimo z izgradnjo ribjih stez (Horvat, 1993).

Slika 3: Zaplavna pregrada na Bistričici

Figure 3: Check dam constructed on the Bistričica torrent

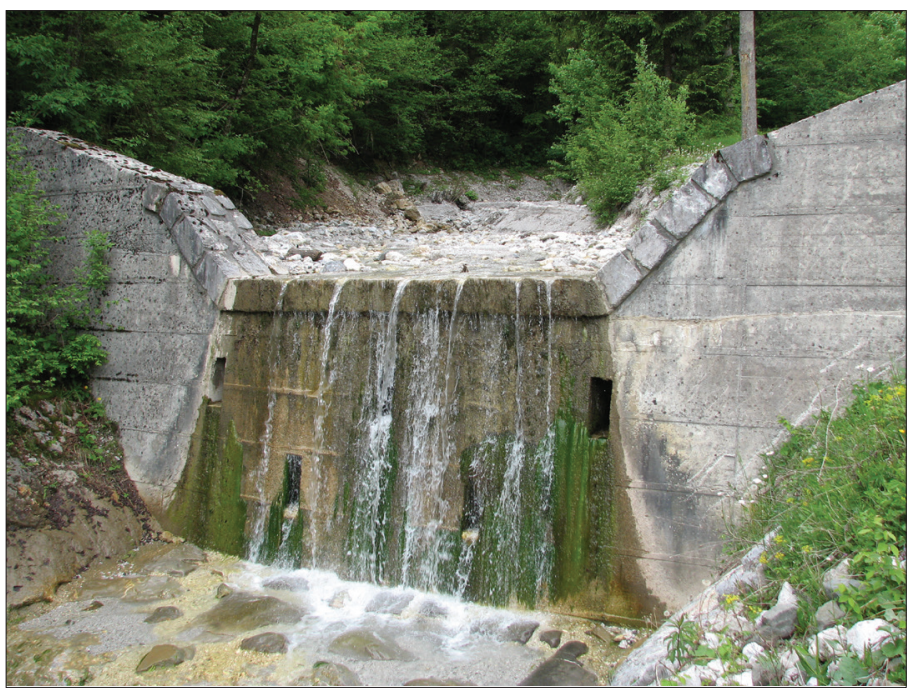

Na hudourniških vodotokih poleg pregrad pogosto zasledimo še t.i. talne pragove. Tudi ti se uvrščajo med prečne objekte in so lahko, podobno kot pregrade, zgrajeni iz različnih materialov - odvisno od tega, kaj želimo z njimi doseči. Pragovi so praviloma precej nižji od pregrad, zato omogočajo nemoteno prehajanje ribjih populacij in imajo manjši negativni vpliv na okolje. Gradimo jih predvsem v spodnjih delih hudournikov, kjer se strmec že nekoliko zmanjša. Tipične višine pragov so do nekaj deset centimetrov (Mikoš, 2000), zato se za njimi niti ne izoblikuje omembe vreden zaplavek. Na odsekih, ki niso v ravnovesju, so pragovi ponavadi razporejeni v nizih po več skupaj. Njihova osnovna vloga je v preprečevanju lokalnega poglabljanja vodotoka in posledično spodkopavanja brežin. Zato jih navadno postavimo v neposredni bližini mostov, na reguliranih odsekih ter na mestih z različnimi obrežnimi zavarovanji. $\mathrm{Na}$ ta način preprečimo spodkopavanje temeljev obrežnih vodnih zgradb, mostov, itd. ter s tem podaljšujemo njihovo življenjsko dobo. 
Med prečne vodogradbene objekte prištevamo še jezove vseh vrst, različne tipe drč, zadrževalnike plavin ter pogojno tudi jezbice. Vsi našteti objekti posredno ali neposredno blažijo vplive škodljivega delovanja voda ob hudourniških poplavah.

Slika 4: Leseni talni pragovi v regulirani strugi Bistričice, ki preprečujejo spodkopavanje obrežnega zavarovanja

Figure 4: Wooden bed sills in the regulated section of the Bistričica torrent for protection of revetment works

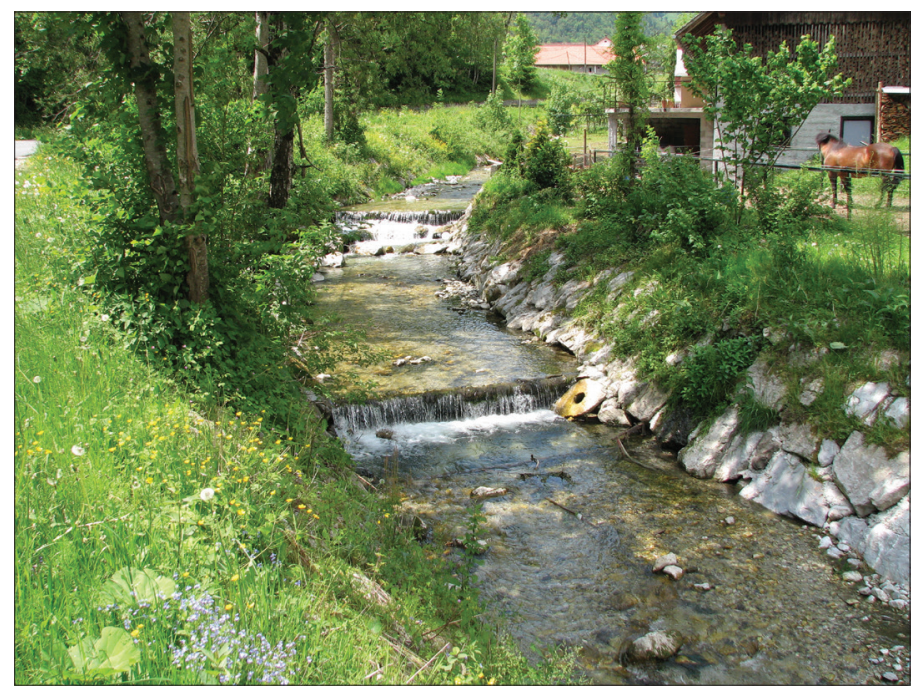

Zadrževalniki plavin so po obliki podobni zaplavnim pregradam, le da so večji in imajo precej obsežnejši zaplavni prostor. Ob hudourniških poplavah se lahko v njem zadržijo večje količine vode in rečnega gradiva ter tako varujejo vršaje in dolinska dna pred hudourniškimi poplavami in naplavljanjem. Navadno so postavljeni v zgornjem delu, oziroma na vratu vršaja (Mikoš, 2009). Po vsaki obsežnejši hudourniški poplavi je potrebno odstraniti plavine iz zaplavnega prostora, sicer zadrževalnik plavin ne služi več svojemu namenu. Značilen primer zadrževalnika plavin pri nas je npr. na Bistričici (slika 5), kjer po obilnejših deževjih po potrebi odstranjujejo plavine iz zaplavnega prostora. K zadrževalnikom plavin lahko pogojno prištevamo še pregrado na Pišnici, za katero je nastalo umetno jezero Jasna, ter pregrado na Bistrici v Preddvoru, za katero je umetno jezero Črnava. 
Slika 5: Zaplavek gorvodno od zadrževalnika plavin na Bistričici z urejeno dovozno cesto, ki omogoča odvzem plavin

Figure 5: Accumulation formed just upstream of filter dam on the Bistričica torrent, with access road for debris removal

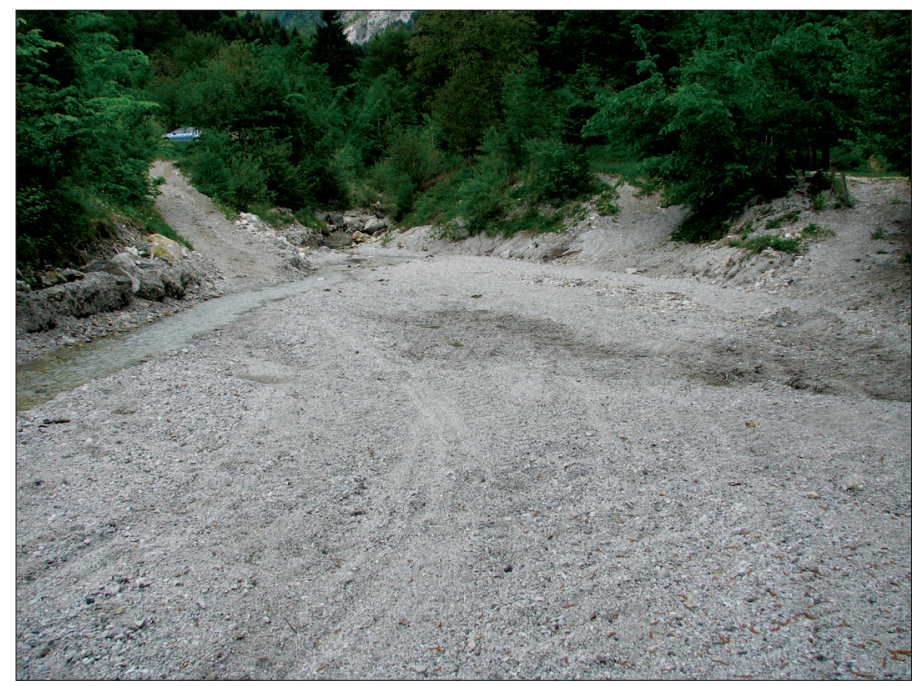

Zadrževalniki plavin so lahko tudi prebiralnega tipa, kar pomeni, da zaradi rež zaustavijo le plavine in plavje nad določeno velikostjo, drobnejši rečni material pa visoke vode nemoteno prenašajo v dolino. Takšen je npr. zadrževalnik plavin v Logu pod Mangartom, ki naselje in dolino varuje pred morebitnim ponovnim drobirskim tokom, kakršen se je dogodil novembra leta 2000 (slika 6) (Komac, 2000; Zorn, Komac, 2002).

Po nekaterih ocenah zavzemajo hudourniška območja v Sloveniji slabo četrtino ozemlja, približno $44 \%$ ozemlja pa je potencialno erozijsko ogroženega. Na okoli 370 hudourniških območjih je približno $1700 \mathrm{~km}$ glavnih hudourniških strug ter več kot $4000 \mathrm{~km}$ pritokov (Horvat, 2002). Na hudourniških vodotokih je bilo do leta 2006 pri nas zgrajenih nekaj manj kot 3500 različnih zaplavnih pregrad, dobrih 3100 pragov ter več kot 200 km različnih obrežnih zavarovanj (Horvat, Jeršič, Papež, 2008). Čeprav so prečne zgradbe v prvi vrsti namenjene preprečevanju erozije, stabilizaciji pobočij ter uravnavanju sproščanja in transporta plavin, je hkrati pomembna tudi njihova protipoplavna funkcija. Z zmanjševanjem strmca namreč do določene mere umirjajo odtok ter s tem zmanjšujejo poplavno ogroženost v dolinah. Obenem tudi zmanjšujejo možnost za nastanek uničujočih drobirskih ali blatnih tokov.

Pri umeščanju prečnih vodogradbenih objektov v prostor je potrebno upoštevati tudi širši okoljski vidik ter jih v čim večji možni meri graditi z naravnimi materiali. Slednji so sicer manj odporni in imajo krajšo življenjsko dobo (Mikoš, 2009), a po drugi strani omogočajo lažjo in učinkovitejšo renaturacijo prizadetih odsekov (Vignozzi in 
sod., 1999). Prečni objekti naj bi bili tudi čim nižji, saj previsoki objekti predstavljajo nepremostljivo oviro za ribje migracije. Višji objekti bi morali imeti ustrezne ribje steze, a se v praksi pogosto izkaže, da so (kadar so slabo projektirane ali nevzdrževane) lahko povsem neučinkovite (Fish passes ..., 2002, Naglič, Juran, 2008).

Slika 6: Zadrževalnik plavin prebiralnega tipa na hudourniku Predelica nad vasjo Log pod Mangartom

Figure 6: A debris-sorting dam on the Predelica torrent upstream the Log pod Mangartom village

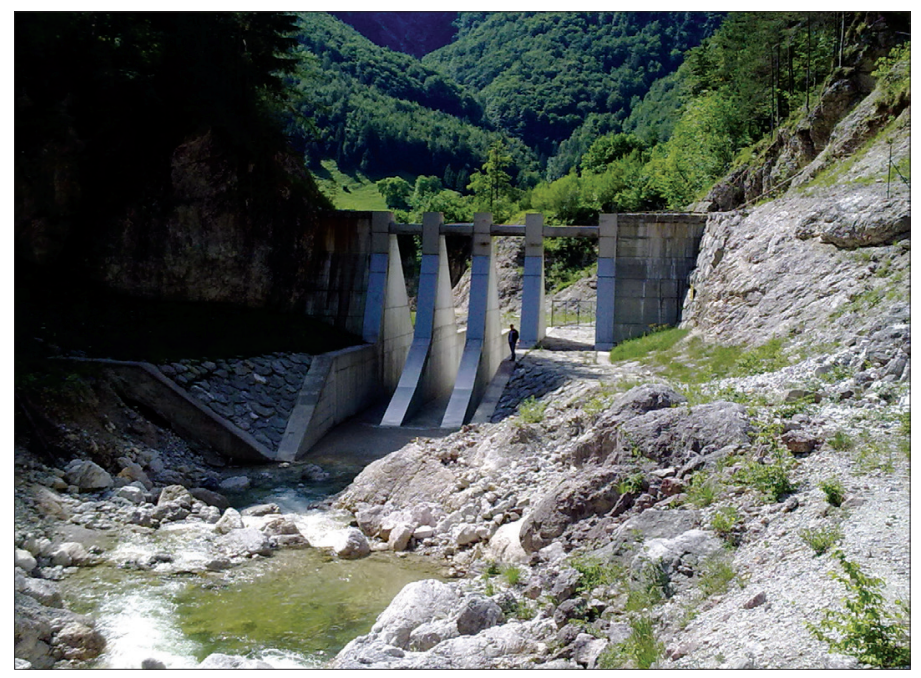

\section{SKLEP}

Slovenija je prepredena s številnimi hudourniškimi vodotoki, ob katerih se ob intenzivnih in obilnih padavinah pogosto pojavljajo hudourniške poplave. Če tovrstnim burnim naravnim dogodkom kakorkoli stojimo na poti, smo zaradi njihove silovitosti izpostavljeni veliki nevarnosti. Da bi zmanjšali nevarnost, smo v preteklosti poskušali varovati mnoga poplavna območja predvsem s pomočjo vodogradbenih protipoplavnih ukrepov, kot so nasipi, zadrževalniki, regulacije in pregradni objekti. Slednje se je ponekod pokazalo za bolj, drugje za manj uspešno, vsekakor pa vodogradbeni ukrepi niso v celoti upravičili svojega cilja, saj hudourniške poplave še vedno ogrožajo številna varovana poplavna območja.

V zadnjem času smo zaradi tega in njihovih negativnih okoljskih učinkov nekoliko bolj zadržani in kritični do tradicionalnih vodogradbenih protipoplavnih ukrepov. Namesto njih prihajajo v ospredje številni in raznoliki negradbeni ukrepi, ki so poleg zmanjševanju nevarnosti namenjeni tudi zmanjševanju ranljivosti. Iz izkušenj smo se naučili, da je borba s poplavami za vsako ceno zgolj s pomočjo vodogradbenih ukrepov nesmiselna ter $\mathrm{z}$ ekonomskega in okoljskega vidika pogosto neupravičena. $\mathrm{K}$ takemu načinu razmišljanja nas je nenazadnje vzpodbudila tudi evropska zakonodaja na področju poplav (Direktiva, 
2007), ki od držav članic terja, da se protipoplavne zaščite v prihodnje lotevajo predvsem s preventivnim ukrepanjem, ki naj bo usmerjeno zlasti v zmanjševanje ranljivosti.

Varstvo pred poplavami je tako preseglo nekdanje okvire in je postalo izrazito interdisciplinarno. Gradbeno-tehnični ukrepi so ostali, njihova vloga znotraj sodobnega koncepta varstva pred poplavami pa se je spremenila. Vodogradbenih protipoplavnih ukrepov ne moremo več povsem enačiti s sodobnim varstvom pred poplavami, temveč jih razumemo kot pomemben sestavni del obvladovanja poplavnega tveganja. Številni vodogradbeni protipoplavni ukrepi so bili do danes že izvedeni, kar se kaže pri načrtovanju dejavnosti na poplavnih območjih. Gradbeno-tehnični protipoplavni ukrepi, kot del sodobnega varstva pred poplavami, ohranjajo svojo dosedanjo vlogo, njihova izvedba pa bi morala biti bolj prilagojena sodobnim spoznanjem. Obnova starejših ureditev mora biti čim bolj sonaravno zasnovana, nove ureditve pa omejene zgolj na najbolj kritična območja. Usklajene morajo biti na ravni celotnega porečja in tudi ne smejo bistveno vplivati na dolvodni režim.

Zaradi nepredvidljive in burne narave so hudourniške poplave med vsemi tipi poplav pri nas najbolj nevarne, tako zaradi velike škode kot izgube človeških življenj. Zaradi njihove izrazite razdiralne moči se je samo z vodogradbenimi protipoplavnimi ukrepi pred njimi še toliko težje (u)braniti. Na območja, ki so izpostavljena hudourniškim poplavam, je v osnovi veliko bolje ne posegati kot pa računati na protipoplavno zaščito. Morebitne že izvedene ureditve na takih območjih načeloma sicer zagotavljajo varnost, a zgolj do izbranega projektnega pretoka, za katerega so bile dimenzionirane. Ko je ta presežen, ali v primeru nepravilnega delovanja ali porušitve zgrajenih protipoplavnih ukrepov, so posledice lahko katastrofalne.

Vse kaže, da se bo v prihodnje zaradi spreminjanja podnebja obseg hudourniških poplav pri nas povečal, kar pomeni, da bodo pretočne konice izrazitejše, hudourniške poplave pa bodo zaradi spremenjenih odtočnih razmer lahko občasno prizadele tudi območja, kjer se do sedaj niso pojavljale. Slednje bo potrebno upoštevati pri prihodnjem poseganju na poplavna območja ter pri obvladovanju poplavnega tveganja na sploh. Pri hudourniških poplavah je najbolj kritičen zelo kratek čas za umik na varno, zaradi česar bo v prihodnje potrebno nameniti še večji poudarek napovedovanju in zgodnjemu opozarjanju na nevarnost. Za zmanjšanje škode ob hudih urah na družbeno sprejemljivo raven bo potrebno postopno zmanjšati predvsem ranljivost, in sicer s preprečitvijo širjenja naselij, infrastrukture in gospodarskih dejavnosti na poplavna območja ter z različnimi negradbenimi in tudi gradbenimi protipoplavnimi ukrepi.

\section{Viri in literatura}

Anzeljc, D., Burja, D., Muck, P., Zupančič, B., 1995. Poplavna ogroženost Slovenije. Ujma, 9, str. 148-155. Ljubljana.

Bates, B. C., Kundzewicz, Z. W., Wu, S., Palutikof, J. P. (ur.), 2008. Climate change and water. IPCC Technical Paper, 6. Genève, Intergovernmental Panel on Climate Change, 214 str.

Brilly, M., 2001. The integrated approach to flash flood management. V: Coping with flash floods. Boston, Kluwer Academic Publishers, str. 103-113. 
Brilly, M., Mikoš, M., Šraj, M., 1999. Vodne ujme: varstvo pred poplavami, erozijo in plazovi. Ljubljana, Fakulteta za gradbeništvo in geodezijo, $186 \mathrm{str}$.

Černe, A., 2005. Pandorina skrinjica - geografski pogledi na prostorske analize v planiranju. Dela, 23, str. 235-244. Ljubljana. URL: http:/www.ff.uni-lj.si/oddelki/geo/ publikacije/dela/files/Dela_23/009_cerne.pdf (Citirano 22. 5. 2011).

Černe M., Ilc, U., 2007. Zagotavljanje poplavne varnosti Železnikov - koncept ureditve Selške Sore. 18. Mišičev vodarski dan, zbornik referatov. Maribor, str. 50-56. URL: http://mvd20.com/LETO2007/R8.pdf (Citirano 10. 5. 2011).

Direktiva 2007/60/ES Evropskega parlamenta in Sveta $z$ dne 23. oktobra 2007 o oceni in obvladovanju poplavne ogroženosti. Bruselj. URL: http://eur-lex.europa.eu/LexUriServ/LexUriServ.do?uri=OJ:L:2007:288:0027:0034:SL:PDF (Citirano 10. 5. 2011).

Fazarinc, R., 2010. Zagotavljanje poplavne varnosti jugozahodnega dela Ljubljane. 21. Mišičev vodarski dan, zbornik referatov. Maribor, str. 30-37. URL: http://mvd20. com/LETO2010/R5.pdf (Citirano 8. 5. 2011).

Fish passes - design, dimensions and monitoring. 2002. Roma, Food and Agriculture Organization of the United Nations in arrangement with Deutscher Verband für Wasserwirtschaft und Kulturbau e.V. (DVWK). URL: http://www.fao.org/docrep/010/ y4454e/y4454e00.htm (Citirano 10. 5. 2011).

FLOODsite, 2009. Flood risk assesment and flood risk management. An introduction and guidance based on experiences and findings of FLOODsite (an EU-funded integrated project). URL: http://www.floodsite.net/html/partner_area/project_docs/FLOODsiteGuidance_v2.zip (Citirano 12. 5. 2011).

Florineth, F., 2004. Pflanzen statt Beton. Handbuch zur Ingenieurbiologie und Vegetationstechnik. Berlin, Patzer Verlag, 272 str..

Guidance on flash flood management. Recent experiences from Central and Eastern Europe, 2007. Associated programme on flood management. URL: http://www.apfm. info/pdf/pilot_projects/APFM-CEE-Synthesis_web.pdf (Citirano 8. 6. 2011).

Horvat, A., 1993. Ekološke osnove urejanja erozijskih območij. Zbornik gozdarstva in lesarstva, 41, str. 5-49. Ljubljana.

Horvat, A., 2002. Erozija. V: Nesreče in varstvo pred njimi. Ljubljana, Uprava RS za zaščito in reševanje Ministrstva za obrambo, str. 267-274.. URL: http://www.sos 112. si/slo/tdocs/nesrece_varstvo1.pdf (Citirano 12. 6. 2011).

Horvat, A., Jeršič, T., Papež., J., 2008. Varstvo pred hudourniki in erozijo ob vse intenzivnejših vremenskih ekstremih. Ujma, 22, str. 200-208. Ljubljana. URL: http://www. sos112.si/slo/tdocs/ujma/2008/200.pdf (Citirano 12. 6. 2011).

Hrvatin, M., 2002. Vodovje. V: Nesreče in varstvo pred njimi. Ljubljana, Uprava RS za zaščito in reševanje Ministrstva za obrambo, str. 55-59. URL: http://www.sos112.si/ slo/tdocs/nesrece_varstvo1.pdf (Citirano 12. 6. 2011).

Kolman, G., Mikoš, M., Povž, M., 2010. Ribji prehodi na hidroenergetskih pregradah v Sloveniji. Varstvo narave, 24, str. 85-96. URL: http://www.zrsvn.si/dokumenti/63/2/2010/Kolman_Mikos_povz_2227.pdf(Citirano 10. 5. 2011).

Komac, B., 2000. Geografski vidiki nesreče. Ujma, 14-15, str. 60-66. Ljubljana. URL: http://www.sos112.si/slo/tdocs/ujma/2001/p3_1.pdf(Citirano 10. 5. 2011). 
Komac, B, Zorn, M., 2007. Pobočni procesi in človek. Ljubljana, Založba ZRC, 217 str. Komac, B., Natek, K., Zorn, M., 2008. Geografski vidiki poplav v Sloveniji. Ljubljana, Založba ZRC, 180 str.

Kozelj, D., Kozelj, K., Steinman, F., Gosar, L., 2008. Poplavna ogroženost in posledice dogodkov preostalega tveganja. Ujma, 22, str. 145-151. Ljubljana. URL: http://www. sos112.si/slo/tdocs/ujma/2008/145.pdf (Citirano 1. 5. 2011).

Kuzmič, R., Suhadolnik, A., 2005. Urejanje voda kot varstvo pred poplavami. 16. Mišičev vodarski dan, zbornik referatov. Maribor, str. 65-71.URL: http://mvd20.com/ LETO2005/R9.pdf (Citirano 1. 5. 2011).

Marušič, I., Penko Seidl, N., Drašler, A., 2005. Pravila za vzdržno urejanje posegov v vode. Končno poročilo. Raziskovalno-razvojni projekt Ciljnega raziskovalnega programa »Konkurenčnost Slovenije 2001-2006«. Ljubljana, Oddelek za krajinsko arhitekturo, Biotehniška fakulteta, 66 str. URL: http:/www.mop.gov.si/filead-

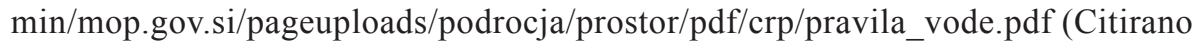
6. 5. 2011).

Mikoš, M., 2000. Urejanje vodotokov (skripta, verzija 01.2000). Ljubljana, Katedra za splošno hidrotehniko, Fakulteta za gradbeništvo in geodezijo, 182 str.

Mikoš, M., 2009. Osnove hudourništva - varstvo pred hudourniki in zemeljskimi plazovi. Ljubljana, Fakulteta za gradbeništvo in geodezijo, 217 str.

Mikoš, M., 2010. Kako zmanjšati poplavne škode v Sloveniji? V: Od razumevanja do upravljanja. Ljubljana, Založba ZRC, str. 255-262. URL: http://giam.zrc-sazu.si/sites/default/files/Naravne-nesrece-01.pdf (Citirano 6. 5. 2011).

Naglič, M., Juran, V., 2008. Pregradni objekti na porečju reke Sore - vpliv na migracijo rib in ekološko sprejemljiv pretok. Varstvo narave, 21, str. 105-123. Ljubljana. URL: http://www.zrsvn.si/dokumenti/63/2/2008/Naglic_1340.pdf (Citirano 12. 5. 2011).

Natek, K., 2002. Ogroženost zaradi naravnih procesov kot strukturni element slovenskih pokrajin. Dela, 18, str. 61-74. Ljubljana. URL: http://www.ff.uni-lj.si/oddelki/geo/ publikacije/dela/files/Dela_18/08\%20natek.pdf (Citirano 9. 5. 2011).

Natek, K., 2005. Poplavna območja v Sloveniji. Geografski obzornik, 52, 1, str. 13-18. Ljubljana. URL: http://zgds.zrc-sazu.si/obzornik/1_2005.pdf (Citirano 28. 5. 2011).

Natek, K., 2007. Geografske dimenzije naravnih nesreč in varstva pred njimi. Dela, 28, str. 147-164. Ljubljana. URL: http://www.ff.uni-lj.si/oddelki/geo/Publikacije/Dela/ files/Dela_28/11_natek.pdf(Citirano 3. 5. 2011).

Papež, J., 2011. Neme priče pri presoji nevarnosti zaradi erozijskih in hudourniških procesov. Magistrsko delo. Ljubljana, Biotehniška fakulteta, 180 str.

Plut, D., 2005. Teoretična in vsebinska zasnova trajnostno sonaravnega napredka. Dela, 23, str. 59-113. Ljubljana. URL: http://www.ff.uni-lj.si/oddelki/geo/publikacije/dela/ files/Dela_23/005_plut.pdf(Citirano 9. 4. 2011).

Pravilnik o metodologiji za določanje območij, ogroženih zaradi poplav in z njimi povezane erozije celinskih voda in morja, ter o načinu razvrščanja zemljišč v razrede ogroženosti. 2007. Uradni list RS, 60 (6. 7. 2007). URL: http://www.uradni-list.si/1/ objava.jsp? urlid $=200760 \&$ stevilka $=3216$ (Citirano 3. 5. 2011). 
Skutnik, B., 2005. Varovanje naselij pred poplavami: Idejna zasnova suhih zadrževalnikov v Spodnji Savinjski dolini. 16. Mišičev vodarski dan, zbornik referatov. Maribor, str. 35-42. URL: http://mvd20.com/LETO2005/R5.pdf (Citirano 8. 5. 2011).

Starec, M., 2002. Varstvo pred poplavami. V: Nesreče in varstvo pred njimi. Ljubljana, Uprava RS za zaščito in reševanje Ministrstva za obrambo, str. 512-522. URL: http:// www.sos 112.si/slo/tdocs/nesrece_varstvo1.pdf (Citirano 8. 5. 2011).

Statistični letopis Republike Slovenije 1999. Varovanje pred poplavami površinskih voda. URL: http://www.stat.si/letopis/1999/32_99/32-16-99.asp?jezik=si (Citirano 14. 5. 2011).

Statistični letopis Republike Slovenije 2004. Urejanje vodotokov in varovanje pred poplavami površinskih voda. URL: http://www.stat.si/letopis/2004/32_04/32-13-04. htm?jezik=si (Citirano 14. 5. 2011).

Steinman, F., Banovec, P., 2008. Hidrotehnika - Vodne zgradbe 1 (skripta). Ljubljana, Fakulteta za gradbeništvo in geodezijo, 115 str.

Šifrer, M., 1983. Vzroki in učinki rečnih poplav na Slovenskem. V: Naravne nesreče v Sloveniji kot naša ogroženost. Ljubljana, Slovenska akademija znanosti in umetnosti, str. 41-49.

Trobec, T., 2008. Hidrogeografske metode ocenjevanja nemerjenih obdobnih pretokov v Sloveniji. Dela, 29, str. 119-130. Ljubljana. URL: http://www.ff.uni-lj.si/oddelki/geo/ Publikacije/Dela/files/dela_29/trobec.pdf (Citirano 18. 5. 2011).

Uredba o pogojih in omejitvah za izvajanje dejavnosti in posegov v prostor na območjih, ogroženih zaradi poplav in z njimi povezane erozije celinskih voda in morja. 2008. Uradni list RS, 89 (19. 9. 2008). URL: http://www.uradni-list.si/1/content?id=88381 (Citirano 14. 5. 2011).

Uredba o vsebini in načinu priprave podrobnejšega načrta zmanjševanja ogroženosti pred poplavami. 2010. Uradni list RS, 7 (29. 1. 2010). URL: http://www.uradni-list.si/1/ content?id $=96007$ (Citirano 14. 5. 2011).

Vannote, R. L., Minshall, G. W., Cummins, K. W., Sedell, J. R., Cushing, C. E., 1980. The river continuum concept. Canadian journal of fisheries and aquatic sciences, 37 , 1, str. 130-137. Ottawa.

Vrhovšek, D., Vovk Korže, A., 2008. Ekoremediacije kanaliziranih vodotokov. Maribor, Limnos, Filozofska fakulteta, Mednarodni center za ekoremediacije, 219 str.

Vignozzi, G., Fratini, R., Nocentini, F., Bartalucci, L., Binazzi, P. P., Bucci, G. L., Saurer, B., Kittl, H., Matos Silva, H., Betamio Almeida, A., 1999. Prevention in the mountains for protection of the valleys - PREMO'98 Final Report: Principles and guidelines for the environmental protection of drainage basins prone to flash floods. URL: http://ec.europa.eu/echo/civil_protection/civil/prote/cpactiv/cpact05g.htm (Citirano 8. 6. 2011).

Ward, R., 1978. Floods - A geographical perspective. London, Macmillan, 244 str.

Wohl, E., 2004. Disconnected rivers - linking rivers to landscape. New Haven, London, Yale University Press, 320 str.

World Meteorological Organization, 2006. Environmental aspects of integrated flood management (WMO-No. 1009). Genève, World Meteorological Organization. URL: http://www.apfm.info/pdf/concept_paper_e.pdf (Citirano 8. 6. 2011). 
World Meteorological Organization, 2009. Integrated flood management - concept paper (WMO-No. 1047). Genève, World Meteorological Organization. URL: http://www. apfm.info/pdf/ifm_environmental_aspects.pdf(Citirano 8. 6. 2011).

Zakon o spremembah in dopolnitvah Zakona o vodah. 2008. Uradni list RS, 57 (10. 6. 2008). URL: http://www.uradni-list.si/1/content?id=86953 (Citirano 8. 6. 2011).

Zorn, M., Komac, B., 2002. Pobočni procesi in drobirski tok v Logu pod Mangartom. Geografski vestnik, 74, 1, 9-23. Ljubljana.

\section{STRUCTURAL MEASURES AS AN INTEGRAL PART OF FLASH FLOOD RISK MANAGEMENT}

\section{Summary}

Slovenia has numerous torrential streams where flash floods and torrential activity can occur during excessive rainfall. If we stand on the way of such impetuous natural hazards, we expose ourselves to great risk. In the past, many structural measures, such as embankments, retention basins, river regulations and river training works have been constructed to reduce hazard on flood-prone areas. River engineering works have proved to be more or less efficient. However, structural measures alone did not fully justify their main purpose, since many protected flood-prone areas are still threatened by flash floods.

While numerous non-structural measures and instruments are coming to the front nowadays, less and less attention is given to traditional structural measures. Non-structural measures are also focused on reducing vulnerability instead of just reducing hazard. Experience has shown that the battle against floods with structural measures only isn't always reasonable and it cannot be allways justified from economic or environmental point of view. Such way of thinking has also been motivated by the demands of European legislation in the field of floods, which requires from member states to cope with floods predominantly in preventive manner, with the emphasis on reducing vulnerability.

The modern concept of flood protection has exceeded its former extent and has recently become very interdisciplinary. However, structural measures are still present but their role in the modern flood risk management concept has been changed. Structural measures are understood as an important integral part of flood risk management rather than the synonymous with flood protection, as they used to be understood in the past. However, nowadays it is hard to imagine flood protection without structural measures simply because many technical solutions have already been applied. The latter fact is also reflected in the protected flood-prone areas planning policies.

Structural measures as an integral part of flood risk management should keep pace with the time. Old river engineering works should eventually be renewed in sustainable manner, while newly constructed measures should be limited to utmost critical areas only. New structures should be consistently applied in the entire river basin and should not affect the downstream river regime significantly.

Because of their unpredictable and impetuous nature, flash floods pose the greatest threat to the loss of lives among all types of floods. Due to their brutal force, it is very 
difficult to protect flood-prone areas even with structural measures. In flash flood areas, it is generally far better to stay away from flood plain than to rely on flood protection. By present technical constructions, relative safety is assured up to the so-called project flood only, which is represented by the assent discharge for which structures have been dimensioned. Whenever project flood is exceeded, the consequences of flooding might become catastrophic. The impact of flooding may also be enhanced by malfunctioning or collapse of structural measures.

It seems inevitable that due to climate change the overall area which is subjected to flash flooding will expand in the future. Peak discharges are expected to increase and flash floods will tend to strike also in the areas which today aren't considered flood-prone. This fact will have to be taken in account when dealing with flood risk management as well as with future interventions in flood-prone areas. With flash floods, the time to escape to safe place is the most critical. Therefore, in the future the greatest emphasis should be given to flood forecasting and warning systems. To reduce flood damage to socially acceptable level, the introduction of new potential for flood damage on flood-prone areas should be restricted in the first place. In addition, flood proofing and, especially, a variety of different non-structural measures should be applied to gradually reduce vulnerability.

(Translated by the author) 